\title{
PENGARUH FAKTOR INTERNAL BANK DAN MAKRO EKONOMI TERHADAP NON PERFORMING FINANCING PERBANKAN SYARIAH DI INDONESIA: PERIODE 2010:01 - 2014:04
}

\section{THE INFLUENCE OF INTERNAL FACTORS AND MACROECONOMIC ON NON PERFORMING FINANCING OF INDONESIAN ISLAMIC BANK IN 2010:01 - 2014:04}

\author{
Haifa $^{1 a}$ Dedi Wibowo ${ }^{2 b}$ \\ 1a Program Studi Timur Tengah dan Islam, Pascasarjana Universitas Indonesia, Jalan Salemba Raya No. 4 \\ Salemba Raya Kode Pos 10440 \\ 2b Program Studi Timur Tengah dan Islam, Pascasarjana Universitas Indonesia, Jalan Salemba Raya No. 4 \\ Salemba Raya Kode Pos 10440 \\ E-mail: 1a haifa_ganiem@yahoo.com,2bbowo15101971@yahoo.com \\ (Diterima oleh Dewan Redaksi: Agustus) \\ (Dipublikasikan oleh Dewan Redaksi: Desember)
}

\begin{abstract}
ABSTRAC
The purpose of this research is to obtain the internal factors (Capital Adequacy Ratio, Financing to Deposit Ratio, Growth Funding and Allocation Ratio A gainst Murabahah Financing on Profit Loss Sharing) and Macro Economics (Inflation and Rupiah A gainst Dollar) the influence of macroeconomics (inflation and rupiah against dollar) on non performing financing islamic bank in Indonesia. The research obtained from combining Islamic bank data, Islamic businnes units stats of syariah bank and monetary indicators which published by bank of Indonesia during January 2010 to April 2014. From the analysis, the hipothesis by using ECM (Error Corection Model) results that the term of leght financing to deposit ratio, ratio allocation against Murabahah financing on profit loss sharing, inflation and rupiah against dollar effect the non performig financing islamic bank in Indonesia. Meanwhile, in the short term the financing to deposit ratio, ratio allocation against Murabahah financing on profit loss sharing, non performing financing was influencig on Islamic bank in Indonesia.
\end{abstract}

Keywords: Risk, Financing, Non Performing Financing, Macro Economics, Islamic Banking, Error Correction Model.

\begin{abstract}
ABSTRAK
Tujuan penelitian ini adalah untuk melihat pengaruh faktor internal (Capital Adequancy Ratio, Financing to Deposit Ratio, Pertumbuhan Pembiayaan dan Rasio Alokasi Pembiayaan Murabahah Terhadap Pembiayaan Profit Loss Sharing) dan Makro Ekonomi (Inflasi dan Kurs Rupiah Terhadap Dolar) terhadap Non Performing Financing perbankan syariah di Indonesia. Penelitian ini menggunakan data gabungan bank umum syariah dan unit usaha syariah dari statistik perbankan syariah dan indikator moneter yang dipublikasikan oleh Bank Indonesia periode Januari 2010 sampai April 2014. Hasil analisis data dengan menggunakan metode ECM (Error Correction Model) menyebutkan bahwa dalam jangka panjang Financing to Deposit Ratio berpengaruh positif terhadap Non Performing Financing, Rasio Alokasi Pembiayaan Murabahah Terhadap Pembiayaan Profit Loss Sharing berpengaruh negatif terhadap Non Performing Financing, Inflasi berpengaruh negatif terhadap Non Performing Financing
\end{abstract}


dan Kurs Rupiah Terhadap Dolar berpengaruh positif terhadap Non Performing Financing perbankan syariah di Indonesia. Dalam jangka pendek Financing to Deposit Ratio berpengaruh positif terhadap Non Performing Financing dan Rasio Alokasi Pembiayaan Murabahah Terhadap Pembiayaan Profit Loss Sharing berpengaruh negatif terhadap Non Performing Financing perbankan syariah di Indonesia.

Haifa. 2015. Pengaruh Faktor Internal Bank dan Makro Ekonomi Terhadap Non Performing Rasio Financing Perbankan Syariah di Indonesia: Periode 2010:01-2014:04 . Jurnal Nisbah(2): $74-87$.

\section{PENDAHULUAN}

Pertumbuhan jumlah pembiayaan yang non performing dalam setahun terakhir mencapai 47,7\% (yoy), lebih tinggi dari tahun 2012 sebesar 26,3\%. Pertumbuhan pembiayaan non performing tersebut melebihi pertumbuhan pembiayaan sehingga rasio NPF (gross) BUS dan UUS meningkat dari 2,2\% pada tahun 2012 menjadi 2,6\% pada tahun 2013 (Grafik 1) sementara pada BPRS, pertumbuhan pembiayaan non performing pada periode 2013 mencapai $32,0 \%$ (yoy), atau melebihi pertumbuhan pembiayaan BPRS dalam periode yang sama. Dengan demikian, sebagaimana pada BUS dan UUS, rasio NPF (gross) BPRS juga mengalami peningkatan dari $6.1 \%$ pada tahun 2012 menjadi $6.5 \%$ pada tahun 2013. Rasio NPF BPRS tersebut lebih tinggi dibandingkan rasio Non Performing Loan industri BPR secara nasional pada posisi yang sama $(4,4 \%)$, akan tetapi masih berada pada posisi yang relatif baik bila dibandingkan kriteria kualitas aset maksimal $7 \%$ pada penilaian tingkat kesehatan BPRS yang tergolong sehat (LPKS, 2013).

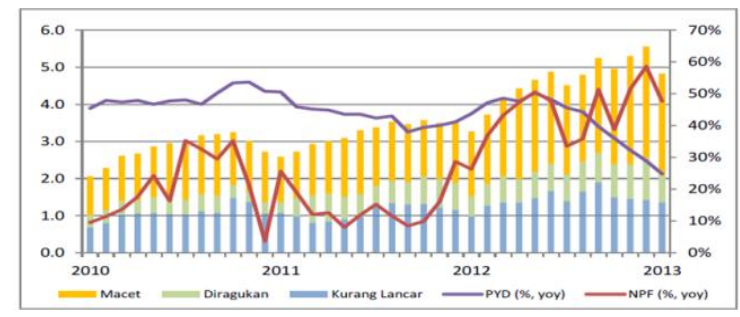

Grafik 1 Perkembangan NPF BUS dan UUS

Periode 2010 - 2013

Sumber: Laporan Perkembangan Keuangan Syariah 0JK, 2013
Berdasarkan laporan perkembangan keuangan syariah 2013 yang dikeluarkan oleh Otoritas Jasa Keuangan (OJK) dikatakan bahwa dari segi pengelolaan risiko, risiko kredit yang dihadapi BUS dan UUS pada tahun 2013 diperkirakan relatif meningkat dibandingkan tahun sebelumnya, meskipun pangsa pembiayaan non performing kurang dari $5 \%$ atau masih dalam batas yang terkendali, namun pertumbuhannya yang cukup signifikan perlu diperhatikan dan dimitigasi lebih lanjut dalam kerangka manajemen risiko yang lebih komprehensif.

Terdapat tiga faktor utama yang menyebabkan terjadinya NPF pada sektor perbankan syariah yaitu faktor intern bank, faktor intern debitur dan faktor ekstern diluar bank maupun debitur. Ditinjau dari sisi intern bank, kelemahan pengelola pembiayaan di bank dan tekanan pihak ketiga, agresifitas bank dalam menyalurkan pembiayaan, lemahnya sistem pengawasan, campur tangan yang berlebihan dari para pemegang saham, jaminan yang tidak memadai dan tidak mengcover pembiayaan (Sutojo, 2000), over dalam agunan, over atau underfinancing, pembiayaan fiktif (Suhardjono, 2003), itikad kurang baik pemilik bank, pengurus atau pegawai bank (Tangkilisan, 2003), bank tidak dapat mengandalkan sarana-sarana contract enforcement yang disediakan oleh hukum (Tangkilisan, 2003).

Dari sisi kelayakan debitur faktor penyebab terjadinya pembiayaan bermasalah di bank adalah 
mismanagement, kurangnya pengetahuan dan pengalaman pemilik usaha dan fraud (Sutojo, 2000), faktor keuangan, manajemen, operasional (Suhardjono, 2003), pemanfaatan iklim persaingan perbankan yang tidak sehat oleh debitur (Tangkilisan, 2003). Penelitian Hadad dkk (2003) menyebutkan ada tiga variabel yang dapat digunakan untuk menilai atau mengukur kemungkinan pailit tidaknya sebuah perusahaan, yaitu dari sisi likuiditas, profitabilitas, dan solvabilitasnya (Hermawan, 2005), sedangkan faktor ekstern bank dan debitur yang dapat mempengaruhi kemungkinan terjadinya NPF adalah penurunan kondisi ekonomi moneter negara, usaha, bencana alam, peraturan pemerintah, peraturan lainnya dimana bersifat membatasi yang berdampak besar pada situasi keuangan dan operasional serta manajemen nasabah (Sutojo, 2000), resesi, devaluasi, inflasi, deflasi dan kebijakan moneter lainnya, meningkatnya tingkat suku bunga pinjaman (Suhardjono, 2003), perubahan kebijaksanaan pemerintah di sektor riil yang meliputi melemahnya kurs nilai tukar mata uang nasional terhadap mata uang asing (Sutojo, 2000), risiko kredit yang meliputi risiko usaha, geografis, keamanan, politik, risiko ketidakpastian, persaingan (Firdaus dan Aryanti, 2003).

\section{MATERI DAN METODE}

\section{Tinjauan Teoritis}

Non Performing Financing/NPF merupakan salah satu tolak ukur kesehatan suatu bank yang dinilai dari lancar-tidaknya pengembalian pembiayaan/investasi yang disalurkan. Secara spesifik ada tiga faktor utama yang menyebabkan terjadinya NPF pada sektor perbankan syariah yaitu faktor intern bank, faktor intern debitur dan faktor ekstern diluar bank maupun debitur.

Penelitian ini difokuskan pada faktor intern bank yang diwakilkan oleh rasio kecukupan modal (CAR), financing to deposit ratio (FDR), pertumbuhan pembiayaan (FING), dan alokasi pembiayaan murabahah terhadap alokasi pembiayaan bagi hasil (RF), dan faktor ekstern/kondisi makro ekonomi yang diwakilkan oleh variabel inflasi dan kurs rupiah terhadap dolar.

Berdasarkan fokus penelitian di atas apat dikembangkan sebuah model hubungan diantara variabel-variabel yang mempengaruhi terjadinya NPF, sebagai berikut :

1. Rasio kecukupan modal (CAR)

CAR adalah perbandingan antara modal sebuah bank terhadap assetnya (yang dibobot berdasarkan resikonya).

CAR yang tinggi mengindikasikan besarnya modal yang dimiliki perbankan syariah yang dapat digunakan untuk menanggung risiko kerugian perbankan salah satunya risiko kredit dan untuk mengantisipasi terjadinya kerugiankerugian yang tidak diinginkan dengan margin yang cukup sehingga lembaga keuangan yang bersangkutan dapat terus beroperasi.

Untuk dapat memastikan bahwa bank dapat menyerap kerugian yang timbul, maka bank harus menjamin bahwa kecukupan modal minimum atau rasio permodalan minimum yang dimiliki oleh bank harus sesuai dengan yang telah ditetapkan oleh Bank Indonesia, yaitu sebesar 8\%.

Berdasarkan peraturan tersebut maka bank yang memiliki tingkat rasio kecukupan modal yang tinggi akan semakin mampu dalam memenuhi pembiayaan dari aktiva yang mengandung risiko, karena CAR juga berfungsi sebagai dasar untuk menetapkan batas maksimum pemberian pembiayaan maka semakin besar kualitas aktiva produktif juga akan berakibat kepada menurunnya tingkat NPF.

2. Financing to Deposit Ratio (FDR)

FDR adalah perbandingan antara pembiayaan yang diberikan oleh bank 
dengan dana pihak ketiga yang berhasil dikerahkan oleh bank. Sehingga semakin tinggi FDR suatu bank, berarti dana pihak ketiga terserap semua ke pembiayaan. Pembiayaan yang tinggi lambat laun dapat menurunkan kualitas dari pembiayaan tersebut. Dari segi kuantitas semakin banyak pembiayaan yang dikeluarkan maka, risiko pembiayaan bermasalah/NPF menjadi lebih besar. Jadi, semakin tinggi FDR semakin tinggi pula NPF. Demikian pula sebaliknya.

\section{Pertumbuhan pembiayaan (FING )}

Pertumbuhan pembiayaan (FING) adalah proses kenaikan nominal pembiayaan perbankan syariah yang terus menerus dalam jangka panjang. Pertumbuhan pembiayaan pada perbankan syariah (FING) dihitung dengan cara berikut

FING $: \frac{\text { Pembiayaan } \mathrm{t}-\text { Pembiayaan } t-1}{\text { Pembiayaan } t-1} \times 100 \%$

Sipahutar (2007) menyatakan, sebagai lembaga finansial, peranan perbankan memang sangat strategis. Bank adalah motor penggerak perekonomian. Perbankan yang mempunyai jumlah pinjaman lebih besar dapat menyebabkan potensi tingginya risiko kredit yang harus ditanggung.

4. Alokasi pembiayaan murabahah terhadap alokasi pembiayaan bagi hasil (RF)

Pembiayaan murabahah dinilai berisiko lebih rendah dan memiliki ekspektasi return yang lebih tepat dibandingkan dengan musyarakah dan mudharabah (Wiliasih, 2005). Hal tersebut menyebabkan akad murabahah menjadi dominan dalam portofolio bank syariah. Sedangkan, menurut Syamsudin (2008), ada beberapa alasan akad murabahah popular dalam operasi perbankan syariah, yaitu pertama, dari sisi bank syariah, murabahah merupakan investasi jangka pendek yang mudah dan likuid, benefit yang berasal dari margin bisa ditentukan dan dipastikan, serta menjauhi ketidakpastian dan meminimalisasi risiko yang ada pada sistem bagi hasil. Kedua, dari sisi nasabah, murabahah tidak memungkinkan bank syariah untuk mencampuri manajemen bisnis. Jika preferensi bank syariah dalam memilih murabahah yang berisiko rendah, dibandingkan alokasi pembiayaan berisiko tinggi diikuti dengan analisis prudensial, maka variabel ini dapat berpengaruh untuk menekan rasio NPF.

\section{Inflasi}

Inflasi dapat berpengaruh terhadap pembiayaan bermasalah, inflasi yang tinggi dan tidak stabil memberikan dampak negatif kepada kondisi sosial ekonomi masyarakat. Inflasi yang tinggi akan menyebabkan menurunnya pendapatan riil masyarakat sehingga standar hidup masyarakat juga turun. Dengan meningkatnya inflasi maka akan mengakibatkan kemampuan nasabah dalam membayar cicilan nasabah juga akan terganggu (Rahmawulan, 2008).

\section{Kurs rupiah terhadap dolar}

Menurut Mutamimah (2013) apabila semakin tinggi nilai tukar rupiah terhadap dollar Amerika (mata uang domestik nilainya turun terhadap mata uang asing) maka debitur ataupun perusahaan yang bergerak dalam bidang importir akan terkena dampak dari perubahan nilai tukar tersebut dan sangat berpengaruh pada kelancaran usaha nasabah apabila usaha tersebut dijalankan menggunakan bahan impor. Hal ini akan mempengaruhi tingginya tingkat pembiayaan bermasalah di perbankan syariah dalam jangka panjang

\section{Metode Penelitian}

Metode analisis untuk menjawab pertanyaan penelitian ini menggunakan pendekatan Error Correction Model (ECM) untuk melihat ada tidaknya 
keseimbangan antara jangka pendek dengan jangka panjang dan menginterpretasikan analisis pengaruh variabel dalam jangka pendek. Sedangkan analisis untuk hubungan jangka panjang ditemukan dari pendekatan hasil regresi Ordinary Least Square (OLS Kointegrasi). Sampel time series yang digunakan dalam penelitian ini adalah Data Gabungan Bank Umum Syariah dan Unit Usaha Syariah yang diambil dari Statistik Perbankan Syariah BI periode Januari 2010 - April 2014. Semua data yang dibutuhkan dalam penelitian ini diambil dari laporan keuangan publikasi BI.

Model awal yang akan digunakan dalam penelitian ini adalah sebagai berikut:

$\mathrm{NPF}=\beta 0+\beta 1 \mathrm{CAR}+\beta 2 \mathrm{FDR}+\beta 3 \mathrm{FING}+$ $\beta 4 \mathrm{RF}+\beta 5$ INFLASI $+\beta 6 \mathrm{LN} \_\mathrm{KURS}+\mathrm{e}$

Dimana :

NPF

CAR

FING : Pertumbuhan pembiayaan

RF : Rasio Piutang Murabahah

FDR

: Rasio Perbandingan antara pembiayaan yang diberikan oleh bank dengan dana pihak ketiga pada perbankan syariah terhadap Pembiayaan Profit Loss Sharing

INFLASI : Inflasi

Ln_KURS : Logaritman Natural dari nilai tukar rupiah terhadap US\$

E

: error term

\section{HASIL DAN PEMBAHASAN}

\section{Analisis Faktor Yang Mempengaruhi Non Performing Financing Perbankan Syariah}

Model ekonometri yang digunakan untuk melihat ada tidaknya pengaruh faktor internal (CAR, FDR, FING, dan RF) dan makro ekonomi (Inflasi dan Kurs) terhadap Non Performing Financing (NPF) Perbankan Syariah. Model ekonometri yang digunakan yaitu model pada persamaan yaitu :

NPF_BS $=\beta 0+\beta 1$ CAR_BS $+\beta 2 F D R \_B S+$ $\beta 3$ FING_BS $+\beta 4$ RF_BS $+\beta 5$ INFLASI + $\beta 6$ Ln_Kurs + e

Model ini diestimasi dengan meggunakan pendekatan Error Correction Model (ECM). Dari hasil analisis data, ditemukan hubungan jangka pendek dan hubungan jangka panjang.

\section{Capital Adequancy Ratio (CAR)}

Ho1 : Rasio Kecukupan Modal (CAR) tidak berpengaruh terhadap Rasio Non

Performing Financing Perbankan Syariah Indonesia

Bank yang memiliki rasio kecukupan modal yang lebih tinggi cenderung dikelola secara lebih baik. Artinya, CAR merupakan faktor kunci yang menentukan apakah moral hazard dapat dihindari atau tidak. Makin tinggi CAR, makin rendah terjadinya kecenderungan pemilik bank menyalah gunakan bank (Sugema,2003 dalam Hermawan, 2005)

Berdasarkan ouput regresi yang dirangkum dalam Tabel 1, diketahui bahwa dalam jangka pendek dan jangka panjang CAR tidak signifikan berpengaruh terhadap NPF Perbankan Syariah.

Tabel 1. Hasil Regresi CAR terhadap NPF

\begin{tabular}{lccl}
\hline $\begin{array}{c}\text { Pengaruh } \\
\text { Terhadap } \\
\text { NPF }\end{array}$ & Koefisien & Prob & Kesimpulan \\
\hline Jangka & - & 0.8850 & Tidak \\
Pendek & 0.003591 & & Signifikan \\
Jangka & 0.014825 & 0.5936 & Tidak \\
Panjang & & & Signifikan \\
\hline
\end{tabular}

Sumber : Diolah dari hasil penelitian

Berdasarkan Tabel 1 diketahui bahwa dalam jangka pendek dan jangka panjang nilai probabilitas masing-masing sebesar 0.8850 dan 0.5936 nilai tersebut lebih dari 0.05 Dengan demikian Ho1 diterima 
sehingga dapat disimpulkan bahwa dalam jangka pendek dan jangka panjang CAR tidak signifikan berpengaruh terhadap NPF.

Hasil penelitian ini mengindikasikan bahwa peningkatan atau penurunan CAR selama periode penelitian tidak akan mempengaruhi NPF. Semakin besar CAR maka semakin tinggi kemampuan permodalan bank dalam menjaga kemungkinan timbulnya risiko kerugian kegiatan usahanya namun belum tentu secara nyata berpengaruh terhadap peningkatan NPF perbankan syariah. Di sisi lain, CAR perbankan syariah yang tinggi dapat mengurangi kemampuan bank dalam melakukan ekspansi usahanya seperti penyaluran kredit karena semakin besarnya cadangan modal yang digunakan untuk menutupi risiko kerugian. Rata - rata CAR perbankan syariah pada periode Januari 2010 - April 2014 berada pada kisaran yang cukup tinggi yakni $15.10 \%$, jauh diatas ketentuan minimal yang disyaratkan oleh Bank Indonesia sebesar $8 \%$.

Tingginya CAR mengindikasikan adanya sumber daya finansial (modal) yang idle. Tingginya nilai CAR mungkin disebabkan oleh sebagian besar dana yang telah diperoleh dari aktivitas perbankan dialokasikan pada cadangan minimum bank atau digunakan untuk menutupi potensi kerugian yang diakibatkan oleh kegiatan aktivitas bank seperti pembiayaan bermasalah.

\section{Financing To Deposit Ratio (FDR)}

Ho2 : Financing to Deposit Ratio

(FDR) tidak berpengaruh terhadap rasio Non Performing Financing Perbankan Syariah Indonea

Dengan nilai FDR yang tinggi namun masih dalam batas nilai optimum yaitu rata-rata sebesar 97,24\% di mana sesuai ketentuan Bank Indonesia dianggap sehat, menunjukkan bahwa dari jumlah dana yang tersedia di sektor perbankan dapat digunakan secara maksimal dalam bentuk kredit sebagai asset yang dianggap paling produktif. FDR merupakan perbandingan antara total jumlah pembiayaan yang disalurkan dibandingkan dengan total dana pihak ketiga. FDR yang tinggi berarti adanya penyaluran kredit yang tinggi pula. Dengan demikian risiko terjadinya NPF tinggi pula. Jadi semakin tinggi FDR maka semakin tinggi pula NPF. Demikian pula sebaliknya. Sehingga bila terjadi NPF, bank harus menanggung beban kerugian dan pada akhirnya dibutuhkan modal untuk menutup kerugian tersebut.

Berdasarkan ouput regresi yang dirangkum dalam Tabel 2, diketahui bahwa dalam jangka pendek dan jangka panjang FDR berkorelasi positif dan signifikan terhadap NPF Perbankan Syariah.

Tabel 2. Hasil Regresi FDR terhadap NPF

\begin{tabular}{|c|c|c|c|}
\hline $\begin{array}{c}\text { Pengaruh } \\
\text { Terhadap } \\
\text { NPF }\end{array}$ & Koefisien & Prob & Kesimpulan \\
\hline Jangka & 0.045996 & 0.0024 & Positif \\
\hline Pendek & & & Signifikan \\
\hline Jangka & 0.053506 & 0.0006 & Positif \\
\hline Panjang & & & Signifikan \\
\hline
\end{tabular}

Sumber : Diolah dari hasil penelitian

Berdasarkan Tabel 2 diketahui bahwa dalam jangka pendek dan jangka panjang nilai probabilitas masing-masing sebesar 0.0024 dan 0.0006 nilai tersebut kurang dari 0.05 Dengan demikian Ho2 ditolak, sehingga dapat disimpulkan bahwa dalam jangka pendek dan jangka panjang FDR signifikan berpengaruh terhadap NPF. Sedangkan arah koefisien variabel FDR dalam jangka pendek (DFDR) dan jangka panjang searah dan bernilai positif, di mana kenaikan $1 \%$ dari FDR meningkatkan $\quad 0.054 \%$ NPF pada keseimbangan jangka panjang dan peningkatan 1\% dari perubahan FDR periode sebelumnya, mengakibatkan perubahan rasio NPF jangka pendek sebesar $0.046 \%$. 
Financing To Deposit Ratio (FDR) merupakan perbandingan total pembiayaan yang diberikan dibandingkan dengan total dana pihak ketiga. Semakin tinggi FDR maka semakin baik pula dampaknya dalam menggerakan roda ekonomi nasional karena FDR dapat mendongkrak laju pertumbuhan ekonomi. Mustahil perekonomian bisa maju jika tidak didukung oleh keterlibatan penuh dari dunia perbankan. Tingginya FDR berarti adanya penyaluran pembiayaan yang tinggi pula. Namun, hasil penelitian mengindikasikan bahwa pembiayaan yang disalurkan perbankan syariah kepada setiap nasabahnya, berkualitas buruk, sehingga ekspansi pembiayaan yang dilakukan perbankan syariah dapat meningkatkan rasio NPFnya.

\section{Financing Growth / Pertumbuhan Pembiayaan (FING)}

Ho3 : Pertumbuhan Pembiayaan (FING) tidak berpengaruh terhadap Rasio Non Performing Financing Perbankan Syariah Indonesia

Berdasarkan ouput regresi yang dirangkum dalam Tabel 3, diketahui bahwa dalam jangka pendek dan jangka panjang FING tidak signifikan berpengaruh terhadap NPF Perbankan Syariah.

Tabel 3. Hasil Regresi FING terhadap NPF

\begin{tabular}{lccl}
\hline $\begin{array}{c}\text { Pengaruh } \\
\text { Terhadap } \\
\text { NPF }\end{array}$ & Koefisien & Prob & Kesimpulan \\
\hline Jangka & - & 0.0941 & Tidak \\
Pendek & 0.008070 & & Signifikan \\
Jangka & 0.006458 & 0.2875 & $\begin{array}{l}\text { Tidak } \\
\text { Panjang }\end{array}$ \\
\hline
\end{tabular}

Sumber : Diolah dari hasil penelitian

Berdasarkan Tabel 3 diketahui bahwa dalam jangka pendek dan jangka panjang nilai probabilitas masing-masing sebesar 0.0941 dan 0.2875 nilai tersebut lebih dari 0.05. Dengan demikian Ho3 diterima, sehingga dapat disimpulkan bahwa dalam jangka pendek dan jangka panjang FING tidak signifikan berpengaruh terhadap NPF.

Perubahan (kenaikan dan penurunan) pada penyaluran pembiayaan secara nyata tidak akan mempengaruhi NPF pada perbankan syariah. Hal ini terjadi karena nilai NPF pada periode penelitian Januari 2010 - Mei 2014 berkisar antara nilai $2.2 \%$ - 4.7\%. Meskipun NPF menunjukkan nilai yang cukup tinggi (hampir mendekati 5\%) namun perbankan syariah memiliki Capital Adequacy Ratio (CAR) yang cukup tinggi dan jauh dari batas minimum yang ditetapkan oleh Bank Indonesia. Sehingga CAR tersebut masih dapat membantu mengcover risiko pembiayaan yang diakibatkan oleh pembiayaan bermasalah. Oleh karena itu pertumbuhan pembiayaan secara nyata tidak mengakibatkan menurun/meningkatnya NPF dan demikian pula sebaliknya.

\section{Rasio Alokasi Pembiayaan Murabahah Terhadap Pembiayaan Profit Loss Sharing (RF)}

\begin{tabular}{|c|c|c|}
\hline Ho4 & Alokasi & Pembiayaan \\
\hline Murabahah & terhadap & Aloka \\
\hline Pembiayaan & Bagi Hasil & \\
\hline Performing & Financing & \\
\hline
\end{tabular}
Berdasarkan ouput regresi yang dirangkum dalam Tabel 4, diketahui bahwa dalam jangka pendek dan jangka panjang $\mathrm{RF}$ berkorelasi positif dan signifikan terhadap NPF Perbankan Syariah.

Tabel 4. Hasil Regresi RF terhadap NPF

\begin{tabular}{cccl}
\hline $\begin{array}{c}\text { Pengaruh } \\
\text { Terhadap } \\
\text { NPF }\end{array}$ & Koefisien & Prob & Kesimpulan \\
\hline Jangka & - & 0.0321 & Negatif \\
Pendek & 0.016980 & & Signifikan \\
Jangka & - & 0.0000 & Negatif \\
Panjang & 0.030026 & & Signifikan \\
\hline
\end{tabular}

Sumber : Diolah dari hasil penelitian 
Berdasarkan Tabel 4 diketahui bahwa dalam jangka pendek dan jangka panjang nilai probabilitas masing-masing sebesar 0.0321 dan 0.0000 nilai tersebut kurang dari 0.05. Dengan demikian Ho4 ditolak sehingga dapat disimpulkan bahwa dalam jangka pendek dan jangka panjang $\mathrm{RF}$ signifikan berpengaruh terhadap NPF, sedangkan arah koefisien variabel $\mathrm{RF}$ dalam jangka pendek (DRF) dan jangka panjang searah dan bernilai negatif, dimana kenaikan $1 \%$ dari $\mathrm{RF}$ menurunkan $\quad 0.030 \% \quad \mathrm{NPF}$ pada keseimbangan jangka panjang dan peningkatan $1 \%$ dari perubahan $\mathrm{RF}$ periode sebelumnya, mengakibatkan perubahan rasio NPF jangka pendek turun sebesar $0.017 \%$.

Koefisien negatif dalam variabel $\mathrm{RF}$ pada jangka panjang dan pendek sesuai dengan hipotesis penelitian yang diajukan oleh Wiliasih (2005), di mana preferensi dari pihak manajemen yang menilai bahwa risiko murabahah lebih kecil. Skim murabahah juga membuat return yang diperoleh di masa depan lebih dapat diekspektasikan, sehingga membuat level NPF menjadi lebih kecil.

Setidaknya, selain karena tingkat risiko yang rendah pada skim murabahah, ada dua hal yang juga mendukung tren murabahah dalam bank syariah. Pertama, tren murabahah didukung karena sumber pendanaan banyak berasal dari jangka pendek, seperti giro dan deposito 1 bulan. Jika bank syariah memaksa untuk mengalokasikan pembiayaan pada jangka panjang, maka hal tersebut dapat menyebabkan risiko mismatch atau kesenjangan antara jatuh tempo pembiayaan dengan sumber pendanaan, yang pada akhirnya berpengaruh pada likuiditas (Ismal, 2011). Masih dominannya sumber DPK jangka pendek, membuat bank berhati-hati dalam memutuskan kebijakan pembiayaan yang diambil. Murabahah banyak diterapkan dalam pembiayaan jangka pendek (Khan dan ahmed, 2011), sehingga risiko likuiditas dalam akad ini relatif dapat dikelola. Selain itu, dengan menerapkan akad murabahah, juga membuat bank dapat memprediksi bagi hasil yang diberikan untuk simpanan. Kedua, murabahah masih menjadi tren karena sederhana dan tidak asing terutama bagi yang sudah biasa berinteraksi dengan bank konvensional. Apalagi sumber daya internal bank syariah kebanyakan berasal dari karyawan yang sebelumnya pernah bekerja di konvensional (Bariyah, 2006).

Dalam jangka pendek kita ketahui bahwa alokasi piutang murabahah terhadap profit loss sharing (RF) memiliki hubungan negatif signifikan artinya. Peningkatan perubahan rasio pembiayaan murabahah per pembiayaan profit loss sharing akan berdampak pada penurunan rasio NPF.

Signifikansi variabel RF dalam jangka panjang dan jangka pendek menunjukkan adanya keseimbangan baik dalam jangka pendek dan jangka panjang. Namun, kontribusi murabahah dalam menurunkan tingkat risiko pembiayaan tidak selamanya efektif, karena risiko pasti selalu ada. Hal tersebut didukung oleh penelitian Wiliasih (2005), yang mengatakan bahwa non performing financing dalam pembiayaan murabahah juga banyak terjadi. Wiliasih mengambil contoh dalam laporan keuangan BSM tahun 2004, 2,75\% pembiayaan murabahah mengalami kemacetan. Lebih lanjut lagi, Wiliasih (2005) juga mengatakan bahwa penyebab non performing financing bukan sepenuhnya karena pembiayaan mudharabah dan musyarakah, namun juga pembiayaan yang semestinya low risk seperti murabahah.

Menurut Wiliasih (2005) Ada 2 hal yang dapat menjelaskan mengapa murabahah yang memiliki risiko rendah menyebabkan terjadi macet untuk murabahah: (1) kesalahan bank melakukan assessment terhadap calon debitur, kesalahan dalam melakukan 
assessment terhadap calon debitur ini dimungkinkan karena bank syariah belum memiliki sistem khusus dalam menilai kelayakan calon nasabah. Belum adanya kredit biro di Indonesia semakin memperburuk situasi ini. Karena dalam mengatasi hal ini, keberadaan pusat informasi yang menyediakan list debitur yang tidak bertanggung jawab sangat dibutuhkan, sehingga tidak terjadi kasus debitur yang ditolak di konvensional, lari ke bank syariah. Adanya sistem rating dalam proses screening calon nasabah mungkin bisa menghasilkan penilaian yang lebih tepat. (2) bank kurang melakukan monitoring khususnya kepada nasabah murabahah. Fokus kepada nasabah mudharabah dan musyarakah bisa jadi menyebabkan bank jadi kurang melakukan pengawasan dan monitoring yang lebih intensif terhadap pembiayaan murabahah. Kelalaian dalam melakukan monitoring bisa menyebabkan terjadinya moral hazard di sisi nasabah, misalnya nasabah menjadi malas membayar cicilan.

\section{Inflasi}

Ho5 : Inflasi tidak berpengaruh terhadap Non Performing Financing Perbankan Syariah Indonesia

Seorang debitur masih sanggup untuk membayar angsuran kreditnya sebelum inflasi meningkat, namun setelah inflasi terjadi, harga-harga mengalami peningkatan yang cukup tinggi, sedangkan penghasilan debitur tersebut tidak mengalami peningkatan, maka kemampuan debitur tersebut dalam membayar angsurannya menjadi melemah sebab sebagian besar atau bahkan seluruh penghasilannya sudah digunakan untuk memenuhi kebutuhan rumah tangga sebagai akibat dari hargaharga yang meningkat.

Kondisi tersebut akan menyebabkan debitur tidak dapat membayar angsuran kreditnya. Dan jika sebagian besar debitur bank tidak dapat membayar angsuran kreditnya maka dapat dipastikan Non Performing Financing (NPF) bank syariah akan meningkat.

Ouput regresi yang dirangkum dalam Tabel 5, diketahui Inflasi berkorelasi negatif dan signifikan dalam jangka panjang berpengaruh terhadap NPF Perbankan Syariah. Sedangkan, dalam jangka pendek inflasi tidak signifikan berpengaruh terhadap NPF Perbankan Syariah.

Tabel 5. Hasil Regresi Inflasi terhadap NPF

\begin{tabular}{llll}
\hline $\begin{array}{c}\text { Pengaruh } \\
\text { Terhadap } \\
\text { NPF }\end{array}$ & Koefisien & Prob & Kesimpulan \\
\hline Jangka & - & 0.2430 & Tidak \\
Pendek & 0.076796 & & Signifikan \\
Jangka & - & 0.0235 & Negatif \\
Panjang & 0.102790 & & Signifikan \\
\hline
\end{tabular}

Sumber : Diolah dari hasil penelitian

Berdasarkan Tabel 5 diketahui bahwa dalam jangka panjang diperoleh nilai probabilitas 0.0235 nilai tersebut kurang dari 0.05. Dengan demikian Ho5 ditolak sehingga dapat disimpulkan bahwa dalam jangka panjang Inflasi signifikan berpengaruh terhadap NPF. Sedangkan arah koefisien variabel inflasi dalam jangka panjang searah dan bernilai negatif, dimana kenaikan $1 \%$ dari inflasi menurunkan $\quad 0.10 \% \quad$ NPF pada keseimbangan jangka panjang. Sedangkan dalam jangka pendek diperoleh nilai probabilitas sebesar 0.2430 nilai tersebut lebih dari 0.05. Dengan demikian Ho5 diterima, sehingga dapat disimpulkan bahwa dalam jangka pendek perubahan inflasi periode sebelumnya tidak berpengaruh terhadap perubahan NPF periode saat ini.

Koefisien Inflasi negatif signifikan dalam hasil regresi jangka panjang. Interpretasinya, dalam hasil penelitian ini inflasi justru mengurangi terjadinya risiko pembiayaan bermasalah/NPF. Hal itu terjadi, karena dua hal (1) konsep perbankan syariah yang berbeda dengan perbankan konvensional, yang tidak terpengaruh oleh suku bunga. pada perbankan konvensional inflasi yang 
tinggi justru akan lebih merugikan pada pembiayaan bank konvensional, karena inflasi akan mendorong bank konvensional untuk menaikkan Suku Bunga Dasar Kredit (SBDK). Saat SBDK naik dan margin murabahah stabil, nasabah pembiayaan akan memiliki opsi untuk memilih pembiayaan konvensional dan pembiayaan syariah. Secara rasional, nasabah akan lebih memilih pembiayaan syariah, sehingga akan menaikkan jumlah pembiayaan syariah yang juga faktor pembagi dalam rasio NPF. Sehingga, jika faktor pembagi ini semakin besar, dapat membawa kepada level NPF yang lebih kecil. (2) Inflasi yang merupakan peningkatan harga umum dalam suatu perekonomian yang berlangsung terus menerus dari waktu ke waktu. Pertumbuhan jumlah uang yang melebihi pertumbuhan sektor riil inilah yang menyebabkan terjadinya inflasi karena mengakibatkan daya beli uang selalu menurun, dan kecenderungan pemberian pinjaman secara berlebihan, padahal disisi lain keadaan seperti ini mengakibatkan pengguna dana mengalami kesulitan dalam pengembalian dana. Sehingga bank syariah bersikap hati-hati dalam pemberian dana (Rahmawulan, 2008).

Kasus debt financing, bagi orang yang meminjam uang dari bank, inflasi justru bisa menguntungkan, karena pada saat pembayaran angsuran kepada bank nilai uang lebih rendah dibandingkan pada saat meminjam. Dalam aplikasi murabahah dimana angsuran bersifa fixed dari awal sampai akhir, inflasi tidak mengubah nilai angsuran yang harus dibayar nasabah kepada bank. Sehingga, saat terjadi kenaikan inflasi dalam jangka panjang, hal ini tidak menurunkan potensi nasabah dalam memenuhi kewajiban kepada bank, karena nasabah sudah dapat merencanakan pengaturan cash flow yang dibutuhkan untuk melunasi pembiayaan murabahah (Kinasih, 2013).
Mutamimah (2012) umumnya kesulitan yang dihadapi perbankan adalah menentukan secara tepat bagaimana risiko kredit tersebut berubah bersamaan dengan perubahan situasi makroekonomi serta berapa lama perubahan ekonomi makro tersebut, dalam hal ini inflasi direspon oleh perbankan. Alasan lain adalah hal ini mengindikasikan bahwa debitur merasa memiliki tanggung jawab atau komitmen untuk memenuhi kewajibannya dalam hal melunasi pinjamannya ke bank, sehingga meskipun inflasi mengalami kenaikan, pembiayaan bermasalah pada bank syariah tidak ikut mengalami kenaikan juga, selain itu adanya akad yang melandasi perjanjian pembiayaan antara shahibul maal dan mudharib yang bersifat mengikat, sehingga meskipun kondisi makroekonomi mengalami penurunan dalam hal ini inflasi meningkat, mudharib (debitur) tetap berkewajiban untuk melunasi pinjamannya.

\section{Kurs Rupiah Terhadap Dolar}

Ho6 : Kurs rupiah terhadap dolar AS tidak berpengaruh terhadap Non Performing Financing Perbankan Syariah Indonesia

Krisis kurs (nilai tukar mata uang), mengakibatkan memburuknya kemampuan perusahaan yang pada gilirannya meningkatkan pembiayaan bermasalah dalam sistem perbankan. Nilai tukar yang semakin terderesiasi melemahkan neraca perusahaan sehingga mengurangi kemampuan investasi dimasa mendatang.

Berdasarkan ouput regresi yang dirangkum dalam Tabel 4.18, diketahui kurs rupiah terhadap dolar berkorelasi positif dan signifikan dalam jangka panjang berpengaruh terhadap NPF Perbankan Syariah. Sedangkan, dalam jangka pendek kurs rupiah terhadap dolar tidak signifikan berpengaruh terhadap NPF Perbankan Syariah. 
Tabel 6. Hasil Regresi Kurs terhadap NPF

\begin{tabular}{cccl}
\hline $\begin{array}{c}\text { Pengaruh } \\
\text { Terhadap } \\
\text { NPF }\end{array}$ & Koefisien & Prob & Kesimpulan \\
\hline Jangka & - & 0.8364 & Tidak \\
Pendek & 0.003926 & & Signifikan \\
Jangka & 0.016374 & 0.0259 & $\begin{array}{l}\text { Positif } \\
\text { Signifikan }\end{array}$ \\
\hline
\end{tabular}

Sumber : Diolah dari hasil penelitian

Berdasarkan Tabel 6 diketahui bahwa dalam jangka panjang diperoleh nilai probabilitas 0.0259 nilai tersebut kurang dari 5\%. Dengan demikian Ha6 diterima, sehingga dapat disimpulkan bahwa dalam jangka panjang kurs signifikan berpengaruh terhadap NPF, sedangkan arah koefisien variabel kurs dalam jangka panjang searah dan bernilai positif, dimana kenaikan $1 \%$ dari kurs menaikkan $\quad 0.016 \%$ NPF pada keseimbangan jangka panjang. Sedangkan dalam jangka pendek diperoleh nilai probabilitas sebesar 0.8364 nilai tersebut lebih dari 0.05. Dengan demikian Ho6 diterima, sehingga dapat disimpulkan bahwa dalam jangka pendek perubahan kurs periode sebelumnya tidak berpengaruh terhadap perubahan NPF periode saat ini.

Krisis kurs (nilai tukar mata uang), dalam hal ini sebagai proxy dari kebijakan moneter, mengakibatkan memburuknya kemampuan perusahaan yang pada gilirannya meningkatkan kredit bermasalah dalam sistem perbankan. Nilai tukar yang semakin terdepresiasi melemahkan neraca perusahaan sehingga mengurangi investasi dimasa mendatang.

Berdasarkan data Jakarta Interbank Spot Dollar Rate (JISDOR) Bank Indonesia tercatat sejak 15 Juli 2013 nilai tukar rupiah terhadap mata uang dolar amerika serikat terus melemah. Dimana, rupiah terkoreksi di level Rp. 10.024 per dolar AS dari sebelumnya Rp. 9.980 (Rahayu, 2013). Dampak dari pelemahan rupiah itu akan membuat pertumbuhan kredit/pembiayaan melambat. Bank Indonesia mengeluarkan sejumlah kebijakan untuk meredam pelemahan rupiah, salah satunya dengan menaikkan suku bunga Fasilitas Simpanan Bank Indonesia (Fasbis rate) kepada bank untuk menempatkan dananya di Bank Indonesia dalam bentuk rupiah. Kebijakan Bank Indonesia ini menyebabkan perbankan syariah akan lebih memilih instrumen BI sebagai tempat menampung aktiva-nya maka, hal ini dapat mengurangi ekspansi pembiayaan perbankan syariah. Menurunnya jumlah pembiayaan perbankan syariah ini akan menaikan tingkat NPF perbankan syariah karena total pembiayaan yang disalurkan merupakan faktor pembagi dalam rasio NPF. Apabila faktor pembagi ini semakin kecil, dapat membawa kepada level NPF yang lebih besar.

Faktor kurs nilai tukar semakin besar pengaruhnya terhadap debitur yang meminjam kredit dalam mata uang asing dan memasarkan produk mereka didalam negeri dengan harga dalam mata uang nasional. Hal ini menyebabkan beban bunga dan pembayaran kembali kredit meningkat sampai diluar batas debitur untuk memikulnya (Sutojo, 2000).

\section{KESIMPULAN DAN IMPLIKASI}

Bedasarkan hasil analisis pengolahan data, dan analisis ekonomi, maka kesimpulan yang dapat diambil dari penelitian ini adalah :

1. Capital Adequancy Ratio (CAR) tidak berpengaruh terhadap Non Performing Financing Perbankan Syariah baik dalam jangka panjang maupun jangka pendek.

2. Financing To Deposit Ratio (FDR) berpengaruh positif terhadap Non Performing Financing Perbankan Syariah baik dalam jangka panjang maupun jangka pendek.

3. Financing Growth (FING) tidak berpengaruh terhadap Non Performing Financing Perbankan 
Syariah baik dalam jangka panjang maupun jangka pendek.

4. Rasio Alokasi Pembiayaan Murabahah Terhadap Pembiayaan Profit Loss Sharing (RF) berpengaruh negatif terhadap Non Performing Financing Perbankan Syariah baik dalam jangka panjang maupun jangka pendek.

5. Inflasi berpengaruh negatif terhadap Non Performing Financing Perbankan Syariah dalam jangka panjang. Namun, dalam jangka pendek inflasi tidak berpengaruh terhadap Non Performing Financing Perbankan Syariah.

6. Kurs berpengaruh positif terhadap Non Performing Financing Perbankan Syariah dalam jangka panjang. Namun, dalam jangka pendek kurs tidak berpengaruh terhadap Non Performing Financing Perbankan Syariah.

7. Perlunya penelitian lanjutan mengenai non performing financing di bank syariah dengan model dan juga variabel yang berbeda sehingga dapat diketahui dengan pasti penyebab terjadinya pembiayaan bermasalah di bank syariah apakah karena kelemahan sistem operasional di bank syariah atau karena faktor lainnya. Penelitian ini hanya dilakukan pada perbankan syariah di Indonesia. Untuk penelitian selanjutnya penelitian semacam ini dapat melibatkan sampel bank syariah dari Negara lain, misalnya malaysia.

1. Menambah periode penelitian agar diperoleh hasil penelitian yang lebih baik lagi terutama untuk membandingkan kondisi moneter pada saat inflasi maupun pada saat pasca inflasi dan prediksinya pada masa mendatang.

2. Melakukan monitoring secara berkala terhadap pembiayaan bermasalah dan melakukan evaluasi terhadap nasabah dan proyek sebelum menyalurkan pembiayaan. Karena dari hasil anisis ditemukan bahwa rasio FDR memberikan pengaruh positif terhadap NPF, hal ini mengindikasikan bahwa pembiayaan yang disalurkan kurang mendapatkan monitoring dan evaluasi.

3. Perlu diketahui secara lebih spesifik apakah pembiayaan murabahah lebih berpotensi menyebabkan pembiayaan bermasalah dibandingkan pembiayaan musyarakah dan mudharabah, sehingga dapat diketahui pembiayaan mana yang lebih menyebabkan NPF.

\section{DAFTAR PUSTAKA}

Al-Qur'anul karim

Antonio, Muhammad Syafii.(2001). Bank Syariah Dari Teori Ke Praktik. Gema Insani.

Ariefianto, Moch.Doddy (2012).

Ekonometrika Esensi dan

Aplikasi Dengan Menggunakan Eviews. Erlangga

Azizi, A. Qodri (2004). Membangun Fondasi Ekonomi Umat, Yogyakarta: Pustaka Pelajar.

Bank Indonesia. Outlook Perbankan Syariah 2014

Dendawijaya, Lukman (2000). Manajemen Lembaga Keuangan. Jakarta: Ghalia Indonesia

Hasibuan, Nurdin (1994). Perkembangan Kredit Macet dan Permasalahannya.

Pengembaangan Perbankan Institut Bankir Indonesia, No. 47.

Herijanto Hendy, (2014), Prisip, Ketentuan, dan Karakteristik Pembiayaan Bank Syariah,http://hendyherijanto.bl ogspot.com/2014/01/prinsipketentuan-dan karakteristik.html. diakses 29 November 2014 jam 19.00 WIB.

Hermawan, Soebagio (2005). Analisis Faktor-Faktor yang Mempengaruhi Terjadinya Non Performing Loan (NPL) Pada 
Bank Umum Komersial. Tesis: Undip

Ihsan, Muntaha (2011). Pengaruh Gross Domestic Product, Inflasi, dan Kebijakan Jenis Pembiayaan Terhadap Rasio Non Performing Financing Bank Umum Syariah di Indonesia Periode 2005-2010. Skripsi : FE UNDIP

Iqbal, Muhammad (2008). Perbandingan Faktor-Faktor Yang Mempengaruhi Pembiayaan Bermasalah Pada Perbankan Syariah Dan Perbankan Konvensional. Tesis:PSKTTI

Joyosumarno, Soebardjo (1994). Upayaupaya Bank Indonesia Dalam Menyelesaikan Kredit Bermasalah, Pengembangan Perbankan Institut Bankir Indonesia, No.47

Khan, Tariqulla dan Ahmad (2011). Risk Management on Analysis of Issues in Islamic Financial Industry. Islamic Research and Training Institute: Islamic Development Bank.

Kinasih, Septrivia Wahyu (2013). Analisis Faktor Determinan Tingkat Risiko Pembiayaan Bank Syariah Pada 2005-2012. Skripsi:FEUI

Mahmoeddin, As (2002). Melacak Kredit Bermasalah, PustakaSinar Harapan, Jakarta.

Mudrajad Kuncoro. (2007). Metode Kuantitatif. Edisi Ketiga. Yogyakarta. UPP STIM YKPN.

Muhamad (2014). Manajemen Dana Bank Syariah. Rajawali Pers

Mutamimah (2012). Analisis Eksternal dan Internal Dalam Menentukan Non Performing Financing Bank Umum Syariah Di Indonesia. Jurnal Bisnis dan Ekonomi

Nasution, Meyviany (2008). FaktorFaktor Yang Berpeluang Menyebabkan Pembiayaan Non Lancar Pembiayaan Murabahah pada Bank Umum Syariah X. Tesis:FEUI
Omar, Mustafa Mohammed dan Razak, Dzuljastri Abdul, (2008). The Performance Neasures of Islamic Banking Based on The Maqasid Framework, paper presented at the IIUM International Accounting Conference (INTAC IV). Malaysia.

Otoritas Jasa Keuangan . Laporan Perkembangan Keuangan Syariah 2013.

Poetry, Zakiyah Dwi (2011). Pengaruh Variabel Makro dan Mikro Terhadap NPL Perbankan Konvensional dan NPF Perbankan Syariah. Jurnal Islamic Finance \& Business Review

Popita, Mares Suci Ana (2013). Analisis Penyebab Terjadinya Non Performing Financing Pada Bank Umum Syariah Di Indonesia. Accounting Analysis Journal

Priatmadja, Sadhana (2011). Pengaruh Inflasi Terhadap Pembiayaan Bermasalah Per Akad Dan Per Sektor Ekonomi Di Bank Syariah ' $X$ '. Tesis:PSKTTI

Rahayu, Nina (2013). Rupiah Terus Melemah, Ini Dampaknya. http://fokus.news.viva.co.id/news /read/431815-rupiah-terusmelemah--ini-dampaknya diakses tanggal 29 November 2014, Jam $21.00 \mathrm{wib}$

Rahmawulan, Yunis (2008). Perbandingan Faktor Penyebab Timbulnya NPL dan NPF pada Perbankan Konvensional dan Syariah di Indonesia. Tesis:PSKTTI UI.

Rivai, Veithzal dan Arviyan Arifin. (2010). Islamic Banking Sistem Bank Islam Bukan Hanya Solusi Menghadapi Krisis Namun Solusi dalam Menghadapi Berbagai Persoalan Perbankan dan Ekonomi Global.

Rohmana, Yana (2010). Ekonometrika Teori dan Aplikasi dengan Eviews. 
Laboatorium Pendidikan Ekonomi dan Koperasi

Setyowati, Desti (2008). Indikasi Moral Hazard dalam Penyaluran Dana Pihak Ketiga (Studi Komparatif Bank Umum Konvensional dan Bank Umum Syariah di Indonesia). Sinergi Vol 12 No.1 Hal 89 -102.

Siamat, Dahlan. (2005). Manajemen Lembaga Keuangan. Jakarta: Lembaga Penerbit fakultas Ekonomi Universitas Indonesia

Suhardjono (2003). Manajemen Perkreditan Usaha Kecil dan Menengah , UPP AMP UKPN. Yogyakarta

Sutojo, Siswanto (2000). Seri Manajemen Bank No.6 - Strategi Manajemen Kredit Bank Umum: Konsep, Teknik dan Kasus, Damar Mulia Pustaka, Jakarta.

Tangklisan, Hessel Nogi S (2003). Manajemen Keuangan Bagi Analisis Kredit Perbankan : Mengelola Kredit Berbasis Good Corporate Governance, Balairung\&Co. Yogyakarta
Toutounchian, Iraj (2009). Islamic Money \& Banking, Integrating Money in Capital Theory, Singapore : John Wiley \& Sons (Asia) Pte.Ltd.

Usman, Hardius (2002). Penggunaan Teknik Ekonometri Pendekatan Populer dan Praktis Dilengkapi Teknik Analisis Dan Pengolahan Data dengan Menggunakan Paket SPSS. PT. RajaGrafindoPersada

Wikutama, Arya (2010). Faktor-Faktor Yang Mempengaruhi Non Performing Loan Bank Pembangunan Daerah (BPD). Tesis : FEUI

Wiliasih, Ranti (2007). Profit Sharing dan Moral Hazard Dalam Penyaluran Dana Pihak Ketiga Bank Umum Syariah di Indonesia. Jurnal Ekonomi dan Pembangunan Indonesia. Vol VIII No. 02 105129.

www.bi.go.id diakses tanggal 24 Oktober 2014 jam 19:00 wib

www.jpnn.com $/ \mathrm{read} / 2014 / 02 / 03 / 2145$

32/OJK-Panggil-Bank-Syariah-

Bermasalah diakses tanggal 29 November 2014 jam 19:00 wib 